\title{
Evidence for p53-Mediated Modulation of Neuronal Viability
}

\author{
Hong Xiang, ${ }^{1}$ Daryl W. Hochman, ${ }^{1}$ Hideyuki Saya, ${ }^{2}$ Toshiyoshi Fujiwara, ${ }^{3}$ Philip A. Schwartzkroin, ${ }^{1}$ and \\ Richard S. Morrison ${ }^{1}$ \\ ${ }^{1}$ Department of Neurological Surgery, University of Washington School of Medicine, Seattle, Washington 98195-6470, \\ ${ }^{2}$ Department of Oncology, Kumamoto University School of Medicine, Kumamoto 860, Japan, and ${ }^{3}$ First Department of \\ Surgery, Okayama University Medical School, 2-5-1 Shikata-cho, Okayama 700, Japan
}

A role for p53-related modulation of neuronal viability has been suggested by the finding that p53 expression is increased in damaged neurons in models of ischemia and epilepsy. These findings were recently extended with the demonstration that mice deficient in p53 ("knock-out" mice) exhibit almost complete protection from seizure-induced brain injury, whereas wild-type mice display significant neuronal cell loss in the hippocampus and other brain regions. Because the p53 knockout mice used in the latter study expressed a global p53 deficiency in all cell types, it was not possible to conclude that protection was conferred by the exclusive absence of p53 in neurons. Therefore, in the present study, we determined whether p53 expression in isolated neurons is directly coupled to a loss of viability associated with excitotoxic challenge. Primary cultures of hippocampal or cortical neurons were derived from animals containing p53 $(+/+,+/-)$ or those deficient in p53 (-/-). p53-Deficient neurons appeared identical to wild- type neurons with respect to morphology, neurofilament expression, and resting levels of intracellular calcium. Neurons containing at least one copy of p53 were severely damaged by exposure to kainic acid or glutamate. Cell damage was assessed by direct cell counting and by nuclear morphology after propidium iodide staining of DNA. In contrast, neurons deficient in p53 $(-/-)$ exhibited little or no damage in response to excitotoxin treatment. Despite their divergent outcomes, p53 $(+/+)$ and p53 $(-/-)$ neurons demonstrated similar sustained elevations in intracellular calcium levels triggered by glutamate exposure. Restoring p53 expression to p53-deficient neurons, using adenovirus-mediated transduction, was sufficient to promote neuronal cell death even in the absence of excitotoxin. These results demonstrate a direct relationship between p53 expression and loss of viability in CNS neurons.

Key words: p53; neurons; brain injury; epilepsy; apoptosis; hippocampus; excitotoxin; adenovirus; $\mathrm{Ca}^{2+}$
There is now a substantial body of evidence indicating that some forms of physiological cell death, such as apoptosis, can be attributed to an active, gene-regulated process (for review, see Williams and Smith, 1993; White, 1996). The intracellular pathways that culminate in cell death involve a complex network of interacting checkpoints that are not fully understood. These systems are composed of both positive and negative regulators of cell survival. The Bcl-2 gene represents one member of an expanding family of proteins that can prevent programmed cell death (e.g., during development) and neuronal cell death after a variety of insults (Vaux et al., 1992; Allsopp et al., 1993; Kane et al., 1993; Zhong et al., 1993; Martinou et al., 1994). A Bcl-2 homolog, Bcl-x, in its long form, will also inhibit apoptosis (Boise et al., 1993). Mice lacking this form of Bcl-x exhibit extensive cell death of immature neurons in both the CNS and peripheral nervous system, underscoring the importance of Bcl-x to neuronal survival (Motoyama et al., 1995). Several genes have also been identified that promote cell death, including Bax, interleukin- $\beta$-converting enzyme, and

\footnotetext{
Received June 24, 1996; revised Aug. 12, 1996; accepted Aug. 20, 1996.

This work was supported in part by American Cancer Society Grant CB-128 to R.S.M. and National Institutes of Health (NIH) Grants NS31775 to R.S.M. and NS18895 to P.A.S., and by NIH Grant DK47754 in support of the virology core facility at the University of Washington. We thank Dr. Mark Kay for his help with adenovirus production, Dr. James Owens for his help with the statistical analysis, Paul Schwartz and Janet Schukar for their photographic expertise, and Yahua Yu and Julie Tubb for their technical expertise. We also thank Drs. Yoshito Kinoshita and Harley Kornblum for critically reading this manuscript.

Correspondence should be addressed to Dr. Richard Morrison, Department of Neurological Surgery, University of Washington School of Medicine, P.O. Box 356470, Seattle, WA 98195-6470.

Copyright (C) 1996 Society for Neuroscience $0270-6474 / 96 / 166753-13 \$ 05.00 / 0$
}

the p53 tumor suppressor gene. All of these gene products have been associated with the nervous system and are likely to be involved in the regulation of neuronal cell death during development, after injury, and in certain pathological states.

Among the mediators of apoptosis, the p53 tumor suppressor gene may have particular relevance to the induction of cell death in the nervous system. The p53 tumor suppressor gene encodes a nuclear phosphoprotein that functions as a key regulator of cellular proliferation and apoptosis. Indeed, p53 induction has recently been associated with neuronal damage in the CNS (Chopp et al., 1992; Li et al., 1994; Sakhi et al., 1994). For example, systemic injection of kainic acid, a potent excitotoxin that produces seizures associated with a defined pattern of neuronal cell loss, induced p53 expression in neurons exhibiting morphological evidence of damage. Furthermore, when kainate was administered to mice deficient in the p53 protein, neuronal cell loss was absent or minimal, suggesting that p53 is required in a cell death pathway mediated by excitotoxic injury (Morrison et al., 1996). Interestingly, an early event in chronic, moderate excitotoxicity appears to be the accumulation of single-strand DNA breaks (Didier et al., 1996). Recent evidence suggests that single-strand DNA breaks, but not other DNA lesions, are capable of inducing p53 accumulation (Jayaraman and Prives, 1995; Lee et al., 1995), potentially providing a molecular link between excitotoxic injury and neuronal cell death.

In the present study, we evaluated whether there is a direct relationship between p53 expression in neurons and loss of viability. Overexpression of the p53 protein in sympathetic neurons 
does not promote apoptosis (Sadoul et al., 1996), consistent with the demonstration that p53-deficient peripheral neurons undergo normal cell death in response to nerve growth factor (NGF) deprivation (Davies and Rosenthal, 1994; Sadoul et al., 1996). In marked contrast, our results demonstrate that p53 plays a requisite and possibly causal role in the death of CNS neurons.

\section{MATERIALS AND METHODS}

p53-deficient mice. Mice deficient in the p53 tumor suppressor gene were generated from a $129 / \mathrm{Sv} \times \mathrm{C} 57 \mathrm{BL} / 6$ background as described previously (Donehower et al., 1992). To assure the genotype of the offspring, matings were generally performed between two p53 $+/+$ mice (for p53 $+/+$ offspring), one p53 $+/+$ and one p53 -/ mouse (for p53 +/offspring), or two $\mathrm{p} 53-/-$ mice (for $\mathrm{p} 53-/-$ offspring). The genotypes of the mating pairs were confirmed as described previously, using PCR and DNA extracted from mouse tails (Timme and Thompson, 1994). In cases in which $-/-$ mice were obtained from matings involving one $+/-$ mouse and one $-/-$ mouse, the offspring were genotyped three separate times to ensure the correct assignment.

Preparation of neuronal cultures. Cortical and hippocampal neurons were obtained from p53 wild-type and p53-deficient newborn mouse brain. Individual cells were initially dissociated by trypsinization $(0.25 \%$ in HBSS, $\mathrm{Ca}^{2+}$ - and $\mathrm{Mg}^{2+}$-free) for $25 \mathrm{~min}$ at $37^{\circ} \mathrm{C}$ and washed twice with HBSS containing $\mathrm{Ca}^{2+}$ and $\mathrm{Mg}^{2+}$ after inactivating the enzyme with trypsin inhibitor. Cells were further dissociated in serum-free Neurobasal medium plus B27 supplement (Life Technologies, Gaithersburg, MD), as described previously (Brewer et al., 1993) by sequential mechanical dissociation using a $22.5 \mathrm{~cm}$ Pasteur pipette with the tip barely firepolished. Cells were then mixed with an equal volume of trypan blue, and dye-excluding cells were counted in a hemocytometer. Cells were plated on poly-D-lysine-coated dishes $(1 \mu \mathrm{g} / \mathrm{ml})$ at $5.6 \times 10^{4}$ cells per $\mathrm{cm}^{2}$ in serum-free Neurobasal medium plus B27 supplement. Neurobasal medium and B27 supplement represent an optimized medium for sustaining the survival of CNS neurons (Brewer et al., 1993). The medium supports long-term survival (several weeks) and suppresses glial growth to $<2 \%$ of the total cell population. The absence of astrocytes was confirmed by the lack of glial fibrillary acidic protein (GFAP) staining (see Results).

Determination of neuronal cell number. The number of viable neurons in a well was determined by counting cells in two premarked reticules (1 $\mathrm{mm}^{2}$ ) at the time of treatment and at various times after treatment. Viable neurons were judged according to the following criteria: (1) neurites were uniform in diameter, smooth in appearance, and at least twice as long as the soma; and (2) somata were normally smooth and round to oval in shape. In contrast, degenerating, nonviable neurons possessed neurites that were fragmented and "beaded," and the soma was rough, condensed, vacuolated, and irregular in shape.

Nuclear morphology was assessed by staining DNA with propidium
Table 1. Intracellular free calcium measurements in glutamate- and kainate-treated p53 $(+/+)$ and p53 $(-/-)$ cortical neurons

Intracellular calcium measurement fura-2 fluorescence ratio $\left(F_{340} / F_{380}\right)$

\begin{tabular}{lllll}
\cline { 3 - 4 } Genotype & Treatment & Baseline & Initial peak & Steady state \\
\hline$+/+$ & Glu & $0.79 \pm 0.34$ & $1.93 \pm 0.23$ & $2.59 \pm 0.32$ \\
$-/-$ & Glu & $0.84 \pm 0.04$ & $1.93 \pm 0.49$ & $2.74 \pm 0.49$ \\
$+/+$ & KA & $0.83 \pm 0.06$ & $1.74 \pm 0.22$ & $1.38 \pm 0.07$ \\
$-/-$ & KA & $0.81 \pm 0.01$ & $1.66 \pm 0.29$ & $1.28 \pm 0.12$
\end{tabular}

Fura-2 fluorescence measurements were made, as described in Materials and Methods. Three distinct phases of fluorescence were detected as seen in Figure 2. The average value for each phase was determined for each experiment in which measurements were made from 32 to 38 cells per field. Results are expressed as the fura-2 fluorescence ratio for 340 and $380 \mathrm{~nm}$ excitation wavelengths. The means \pm SD for each phase of the response were determined using data from five separate experiments. Once the baseline ratio was judged to be stable, glutamate $(50 \mu \mathrm{M})$ or kainate $(40 \mu \mathrm{M})$ was added to the bathing medium and the $F_{340} / F_{380}$ ratio sampled every 2 min. p53 $(+/+)$ and p53 (-/-) neurons did not display a significant difference in the $F_{340} / F_{380}$ ratio at the baseline level $(p>0.24)$ or at any phase after challenge with glutamate $(p>0.53)$ or kainate $(p>0.44)$ (Student's $t$ test).

iodide. Cells were fixed with $4 \%$ paraformaldehyde for $30 \mathrm{~min}$ at room temperature and treated with propidium iodide $(5 \mu \mathrm{g} / \mathrm{ml}$ in PBS). The cells were viewed under fluorescence optics with UV illumination.

Immunocytochemistry. Primary mouse neurons cultured on poly-Dlysine-coated plates were fixed with $4 \%$ paraformaldehyde at room temperature for $30 \mathrm{~min}$ and washed in PBS. Cells were then treated with $0.2 \%$ Triton $\mathrm{X}-100$ for $15 \mathrm{~min}$ at room temperature, and nonspecific binding of antibody was blocked by the addition of $1 \%$ bovine serum albumin (BSA) in PBS for $30 \mathrm{~min}$ at room temperature. Antineurofilament antibody, 1:1000 (Sternberger Monoclonals, Baltimore, MD), anti-glial fibrillary acidic protein, 1:5000 (Dako, Carpinteria, CA), or anti-p53 antibody, 1:500 (DO-1, Oncogene Sciences, Cambridge, MA) were incubated overnight in blocking buffer (1\% BSA in PBS) at $4^{\circ} \mathrm{C}$. Sixteen hours later, the cells were washed 3 times with PBS and incubated for $1 \mathrm{hr}$ at room temperature with biotinylated anti-mouse IgG in $1 \%$ BSA. After washing in PBS, the cells were incubated for $1 \mathrm{hr}$ at room temperature with streptavidin conjugated to horseradish peroxidase in $1 \%$ BSA. After washing, the presence of antigen was detected by incubating the cells in the DAB substrate solution for $6 \mathrm{~min}$. Cells were rinsed with distilled water and coverslipped with an aqueous mounting medium (Fluoromount-G, Southern Biotechnology Associates, Birmingham, AL).

Preparation and titration of the adenovirus vectors. The preparation of nonreplicative recombinant adenovirus deleted in the E1 region, carrying the human wild-type p53 gene under the control of the CMV promoter,

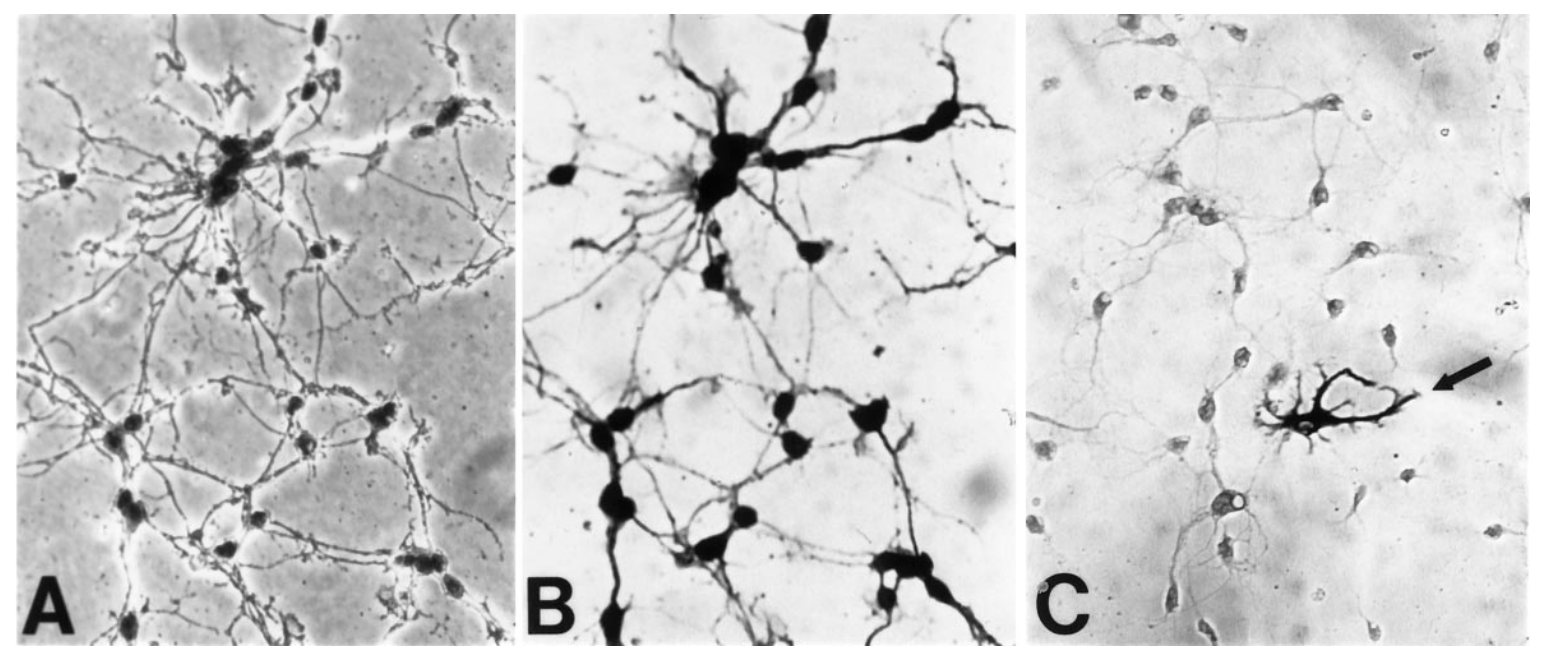

Figure 1. Immunocytochemical characterization of p53-deficient neurons. Cortical neurons derived from p53-deficient mice were prepared and plated as described in Materials and Methods. Cells were viewed under phase-contrast optics $(A)$ and examined for neurofilament expression $(B$, same field as in $A$ ) and expression of GFAP ( $C$, different field) as described in Materials and Methods. The results are representative of six separate wells derived from three different primary cultures. Magnification, $580 \times$. 
was performed as described previously (Zhang et al., 1993). The adenovirus carrying a $\beta$-galactosidase gene, AxCALacZ (Kanegae et al., 1995), was kindly provided by Drs. Saito and Kanegae. Recombinant adenovirus were propagated in E1-complementing 293 cells. Viral stocks were purified in cesium chloride gradients and titered according to the method of Barr et al., 1995.

$\beta$-Galactosidase activity was visualized using $\mathrm{X}-\mathrm{Gal}$ as the substrate. Cells were incubated overnight at $37^{\circ} \mathrm{C}$ in the assay solution containing 4 $\mathrm{mm}$ potassium hexacyanoferrate, $4 \mathrm{~mm}$ potassium ferricyanide, $0.4 \mathrm{mg} / \mathrm{ml}$ $\mathrm{X}-\mathrm{Gal}$, and $4 \mathrm{mM} \mathrm{MgCl}_{2}$ in PBS. Cells were washed with PBS, coverslipped, and checked for blue staining representative of $\beta$-galactosidase staining.

Calcium imaging. Cells were incubated with $6 \mu \mathrm{M}$ fura-2 AM dye (dissolved in equal amounts of DMSO and pluronic acid F-127) for 90 min at $37^{\circ} \mathrm{C}$. The cultures were then washed in HBSS containing $\mathrm{Ca}^{2+} /$ $\mathrm{Mg}^{2+}$ and replenished with a HEPES-buffered balanced salt solution containing (in mM): $\mathrm{NaCl} 140$, $\mathrm{HEPES} 10$, D-glucose $10, \mathrm{KCl} 3, \mathrm{CaCl}_{2} 2$, $\mathrm{MgCl}_{2}$ 1) and maintained in the incubator for another $30 \mathrm{~min}$ to allow for complete hydrolysis of the dye. The cultures were then removed from the incubator and placed on a Nikon inverted microscope at room temperature. Imaging was performed with a CCD camera (CCD-72 camera, Dage MTI) in series with an image intensifier (KS1381, Video Scope International). Cells were excited with a xenon light source; a 340/380 nm pair (250/250 msec exposure) was delivered every $2 \mathrm{~min}$ for at least 60 min. Data acquisition and analysis were controlled by a PC-compatible computer running commercially available software (Universal Imaging, West Chester, PA).

\section{RESULTS}

\section{Characterization of p53-deficient neurons}

Primary neuronal cultures derived from p53-deficient mice were evaluated for the expression of neuronal and glial markers to establish the identity of cells as neurons and to determine their degree of purity. Cultures derived from p53 "knock-out mice" $(-/-)$ and the corresponding wild-type mice $(+/+)$ exhibited similar patterns of immunoreactivity for neurofilament protein and GFAP. Intense immunoreactivity for the neurofilament protein was consistently detected in $\geq 98 \%$ of all p53-/- (Fig. $1 A, B$ ) and p53 $+/+$ cells (data not shown). In contrast, only a few isolated cells expressed GFAP immunoreactivity (Fig. 1C). Cells of both genotypes exhibited identical plating efficiencies, and once plated, neuritic processes and arborizations appeared similar in $+/+$ and $-/-$ cells at each stage of culture. No gross morphological differences were detectable among cells derived from the two genotypes. Similar results were obtained for both cortical and hippocampal preparations.

Wild-type and p53-deficient neurons also exhibited identical resting levels of intracellular calcium (Fig. 2, Table 1). Moreover, the elevation in intracellular calcium levels triggered by glutamate exposure $(50 \mu \mathrm{M})$ was similar for neurons of both genotypes (Fig. 2 , Table 1). These results strongly suggest that the physiological responsiveness of $\mathrm{p} 53$-deficient neurons is not impaired relative to that of their wild-type counterparts.

\section{Neurons lacking p53 are resistant to excitotoxic injury}

A direct role for p53 in initiating neuronal degeneration was assessed by determining the extent of kainate- and glutamatemediated cell death in wild-type $(\mathrm{p} 53+/+)$ and p53-deficient $(-/-)$ neurons. Glutamate or kainate administration induced a significant degree of cell loss in cortical neuronal cultures derived from p53 (+/+) mice (Fig. 3A,B). This effect was both time- and
A) p53+/+, Glu

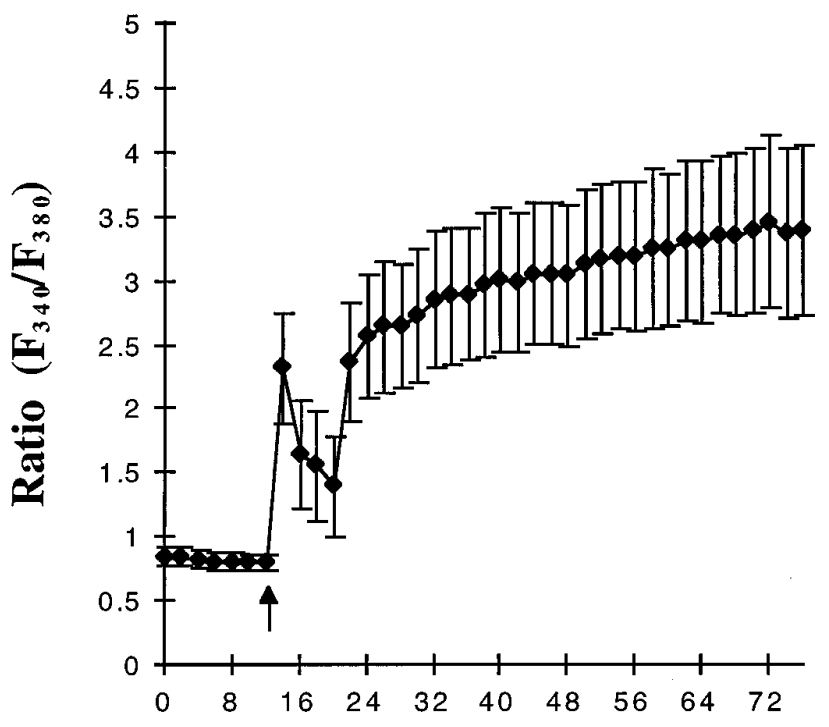

B) p53 -/-, Glu

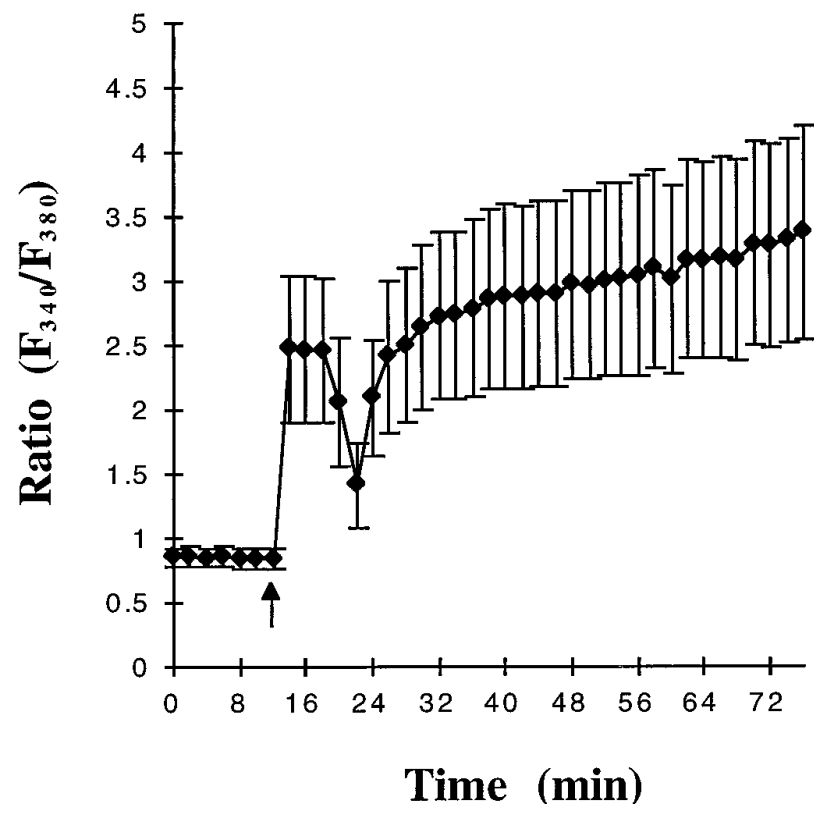

Figure 2. Measurement of intracellular calcium levels during acute glutamate treatment of p53 $(+/+)$ and p53 $(-/-)$ cortical neurons. The resting levels of free cytoplasmic calcium in p53 (+/+) neurons $(A)$ and p $53(-/-)$ neurons $(B)$ and the acute changes induced by glutamate were measured by fura-2 AM videomicroscopy imaging. Addition of $50 \mu \mathrm{M}$ glutamate to the culture is marked by an arrow. The data depict average changes in the fluorescence emission ratio of fura-2 AM (response to $340 \mathrm{~nm}$ illumination/response to $380 \mathrm{~nm}$ illumination) over time for all neurons in a single field. The results represent the mean ratio $\left(F_{340} / F_{380}\right) \pm \mathrm{SD}$ for 39 and 25 cells, respectively, in p53 $(+/+)$ and p53 $(-/-)$ cultures. The changes in calcium triggered by $50 \mu \mathrm{M}$ glutamate exposure were not significantly different between p53 $(+/+)$ and p53 $(-/-)$ cultures (see Table 1$)$. The results shown here for each genotype are representative of results obtained from five different primary cultures. 
A) $\mathrm{p} 53+/+$, Glu

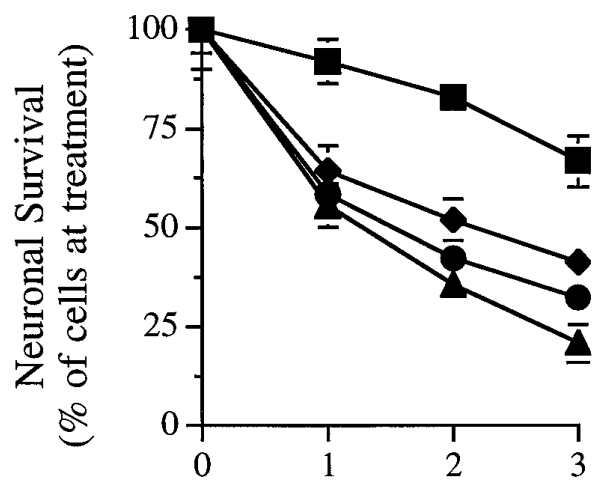

Time (days)

C) p53 +/-, Glu

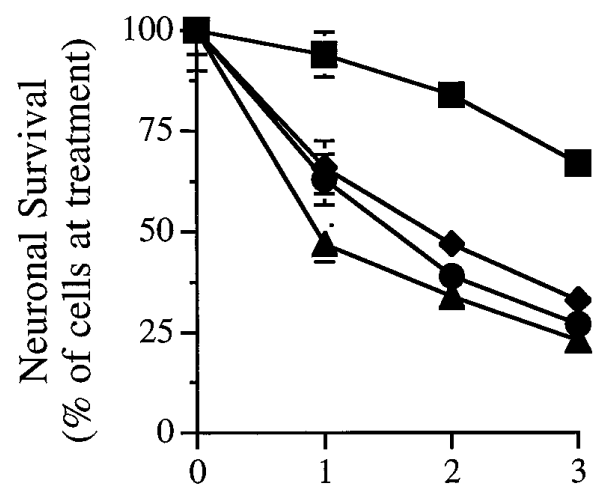

Time (days)

E) p53-/-, Glu

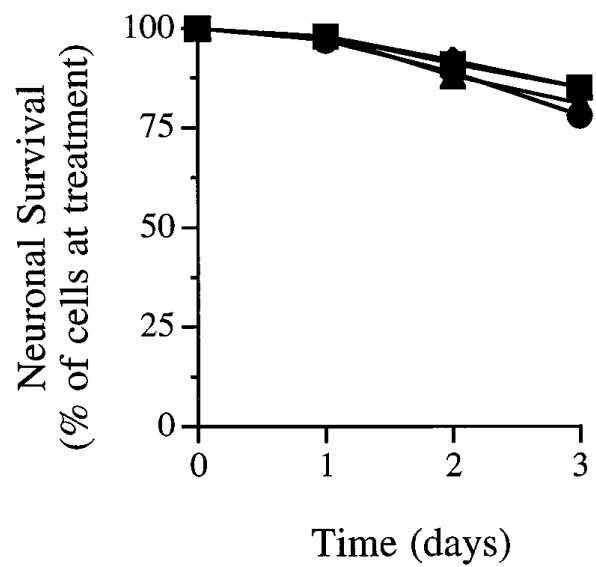

B ) $\mathrm{p} 53+/+, \mathrm{KA}$

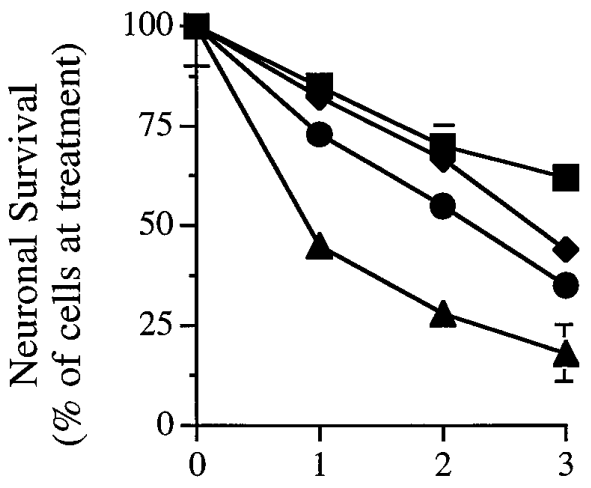

Time (days)

D) $\mathrm{p} 53+/-, \mathrm{KA}$

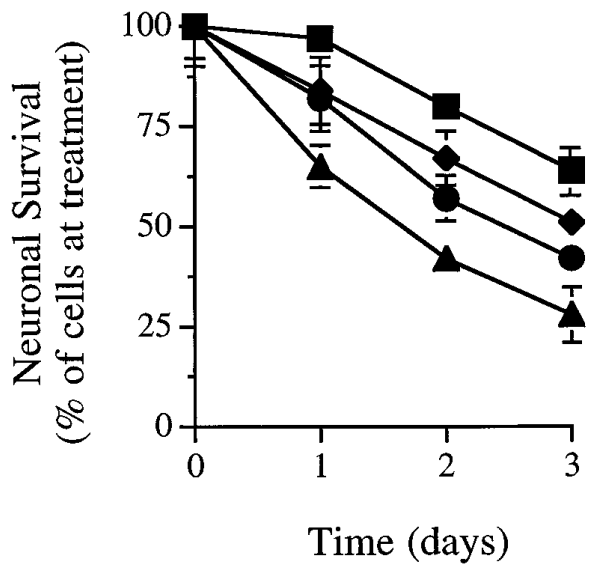

F) p53 -/-, KA

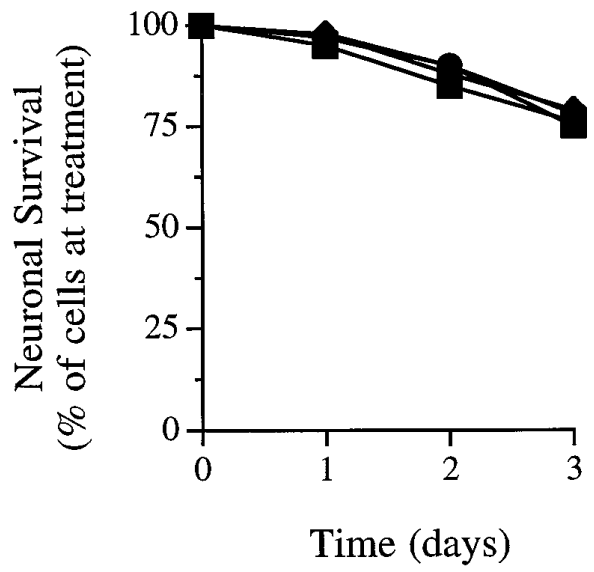

Figure 3. The absence of p53 confers resistance to glutamate- and kainate-mediated cell death. Cortical neurons containing p53 $(+/+,+/-)$ or those deficient in p53 (-/-) were plated and maintained in basal culture conditions for $4 \mathrm{~d}$, as described in Materials and Methods. Cells were subsequently maintained in medium alone (solid squares) or treated with varying concentrations of glutamate (Glu, $25 \mu \mathrm{M}$, solid diamonds; $50 \mu \mathrm{M}$, solid circles; $100 \mu \mathrm{M}$, solid triangles) or kainate $(K A, 20 \mu \mathrm{M}$, solid diamonds; $40 \mu \mathrm{M}$, solid circles; $80 \mu \mathrm{M}$, solid triangles). The cultures were continuously exposed to excitotoxin, and the number of viable neurons then determined after a 1,2, or $3 \mathrm{~d}$ treatment period. Neuronal survival data are expressed relative to the number of cells at the time of treatment (denoted as day 0$)$. All data are the mean $\pm \mathrm{SD}$ of six samples. The p53 $(+/+)(A, B)$ and $(+/-)(C, D)$ genotypes showed significant differences between nontreated cells at all concentrations of glutamate or kainate $(p<0.0005$, ANOVA). Neuronal survival in p53 ( $-/-)$ cultures $(E, F)$ did not differ significantly among nontreated, glutamate-treated, and kainate-treated conditions $(G l u, p>0.30 ; K A, p>0.54$, ANOVA). 
dose-dependent. A significant difference in the percentage of surviving neurons was observed between control and treated neurons as early as $24 \mathrm{hr}(p<0.0005)$, becoming more pronounced with time. Approximately $70-80 \%$ of p53 $(+/+)$ neurons present at the time of treatment were killed $3 \mathrm{~d}$ after adding the highest concentration of glutamate $(100 \mu \mathrm{M})$ or kainate $(80 \mu \mathrm{M})$ tested in these studies. The loss of viability induced by kainate or glutamate treatment was determined not only by direct cell counting but also by evaluating nuclear morphology as assessed by propidium iodide staining of DNA (Ankarcrona et al., 1995). Damaged cells exhibited a highly condensed pattern of nuclear staining, consistent with changes described previously for cells undergoing apoptosis; in contrast, healthy neurons exhibited a larger nucleus containing a diffuse, fibrillar staining pattern. Control cultures under normal incubation conditions were typically characterized by a majority of cells exhibiting large, pale staining nuclei (Fig. $4 A)$. However, $2 \mathrm{~d}$ after glutamate $(50 \mu \mathrm{M})$ or kainate $(40 \mu \mathrm{M})$ treatment, $>50 \%$ of the neurons in p53 $(+/+)$ cultures displayed a condensed, pyknotic, nuclear morphology (Fig. 4C,E). The number of cells expressing an abnormal nuclear morphology was highly correlated with the eventual loss of viable neurons determined by direct cell counting. The temporal pattern and extent of neuronal damage induced by glutamate or kainate did not differ significantly between p53 $(+/+)$ and $(+/-)$ neuronal cultures (Fig. 3A-D).

Mice deficient in p53 (-/-) were resistant to glutamate- and kainate-induced cell death. The percentage of healthy surviving neurons measured after exposure to the highest concentrations of glutamate $(100 \mu \mathrm{M})$ or kainate $(80 \mu \mathrm{M})$ was not significantly different from that seen in control cultures (i.e., nontreated) (glutamate, $p>$ 0.30 ; kainate, $p>0.54$ ). The absence of significant damage and cell loss in p53 $(-/-)$ neuronal cultures was confirmed by propidium iodide staining. Only 14 and 8\%, respectively, of p53 (-/-) neuronal nuclei displayed a condensed, pyknotic morphology $2 \mathrm{~d}$ after glutamate $(50 \mu \mathrm{M})$ or kainate $(40 \mu \mathrm{M})$ treatment (Fig. $4 D, F)$. There was also no morphological evidence to indicate that p53 (-/ $)$ neurons sustained damage; whereas p53 $(+/+)$ neurons displayed condensation of the soma and neurite blebbing and disintegration, p53 (-/-) neurons retained viable processes and cell bodies after excitotoxic challenge (Fig. 4).

The ability of p53-deficient cortical neurons to withstand excitotoxic injury was not unique to neocortical cell types. Identical results were obtained with hippocampal neuronal cultures. In p53 $(+/+)$ hippocampal cultures, kainate $(40 \mu \mathrm{M})$ and glutamate $(50$ $\mu \mathrm{M})$ exposure caused a $50 \%$ neuronal loss, whereas p53 $(-/-)$ hippocampal neurons showed no change in survival relative to nontreated control neurons (Fig. $5 A, B$ ).

Glutamate- and kainate-induced alterations in intracellular calcium levels were evaluated in p53 $(-/-)$ cortical neurons to demonstrate that the resistance to excitotoxic injury did not result from the inability of these excitotoxins to elicit a biological response in the $-/-$ cells. The resting level (baseline) of intracellular calcium was identical for neurons of both genotypes (Fig. 2, Table 1). After the application of glutamate $(50 \mu \mathrm{M})$, there was a rapid elevation in the intracellular level of free calcium, as determined by a three- to fourfold increase in the fluorescence emission ratio $\left(F_{340} / F_{380}\right)$ of fura-2 AM. In some cultures, there was an initial elevation (initial peak) (Table 1, Fig. 2) that lasted for 3-5 min that was followed by a sharp decline back toward baseline levels; this early response was followed by a second sustained (i.e., at least $30 \mathrm{~min}$ ) elevation (steady state) (Table 1, Fig. 2) in intracellular free calcium. Other cultures showed a monotonic rise in $F_{340} / F_{380}$ without the intervening decline. Regardless of the pattern, the glutamate-triggered rise in intracellular calcium observed in p53 $(-/-)$ neurons was not significantly different from the response of $\mathrm{p} 53(+/+)$ neurons $(p>0.53, n=5)$. Similarly, kainic acid application also induced a rapid rise in intracellular calcium levels that was similar for both p53 $(-/-)$ and p53 $(+/+)$ neurons (Table 1) $(p>0.44, n=5)$. These results demonstrate that the failure of excitatory amino acids to promote cell death in p53 (-/-) neurons does not stem from their inability to activate a biological response in these cells.

\section{p53 induces neuronal cell death in the absence of excitotoxic injury}

The resistance displayed by p53-deficient neurons to excitotoxic injury was also consistent with their enhanced rate of survival in the absence of injury (see nontreated controls in Figs. 3 and 5). The percentage of p53 (-/-) neurons surviving in basal growth conditions was significantly greater than that of wild-type and heterozygous neurons after $7 \mathrm{~d}$ in culture $(\%$ mean survival $\pm \mathrm{SD}$; $+/+, 64.66 \pm 7.15 ; \pm, 65.50 \pm 4.46 ;-/-, 81.00 \pm 7.00 ; n=12$, $p<0.0005$, ANOVA). Based on these observations, we investigated the possibility that increased p53 expression could directly promote neuronal cell death even in the absence of injury. The p53 gene was introduced into post-mitotic cortical and hippocampal neurons using adenovirus-mediated transduction. A control virus containing the $\beta$-galactosidase gene (lacZ) was used to determine the efficiency of transduction as well as the effect of viral infection on neuronal viability (Fig. $6 A, B$ ). The number of $\beta$-galactosidase-positive cortical neurons of each genotype increased with time after infection and with increasing viral titer (Fig. 7A, $B$ ). The percentage of $\beta$-galactosidase-positive cells was higher in p53 $(-/-)$ cultures than in p53 $(+/+)$ cultures for each titer of virus. Using virus at a multiplicity of infection (MOI) of $1000, \beta$-galactosidase expression reached maximal levels $48 \mathrm{hr}$ after infection in p53 $(-/-)$ cultures. Expression was maintained at this level for up to 1 week in p53 $(-/-)$ neurons (data not shown). A similar time course for $\beta$-galactosidase expression was observed for wild-type neurons. However, viability was significantly lower using an MOI of 1000 in p53 (+/+) neurons (Fig. $7 D$ ), an effect not seen in neurons lacking p53 (Fig. 7C). Neurons infected with adenovirus that expressed $\beta$-galactosidase displayed healthy cell bodies devoid of chromatin condensation and distinct neuritic processes that produced multiple arborizations. Identical results were obtained with cultured neocortical and hippocampal neurons. These results demonstrate that p53-deficient neurons can be infected with a high degree of efficiency using adenovirus and that the infection process does not alter neuronal survival.

Viability was, however, dramatically reduced in p53-deficient neurons after adenovirus-mediated transduction of the human, wild-type p53 gene. Because infection with an adenovirus containing the $\beta$-galactosidase gene had no effect on neuronal morphology (Fig. $8 A$ ) or survival (Figs. $7 C, 9, L a c Z$ ), this effect was specifically attributed to increased p53 expression. Cortical neurons infected with the adenovirus that expressed the wild-type p53 gene developed pathological morphology (Fig. $8 B$ ) and showed a dramatic decline in viability (Fig. 9, p53) first detected $24 \mathrm{hr}$ after infection. Five days after infection only $5 \%$ of the p53 (-/-) neurons survived. The morphological appearance of neurons in the p53 adenovirus-infected cultures was consistent with their declining viability. Most noticeable was the blebbing and dissolution of neuritic processes, followed by shrinkage in the soma and condensation of the nucleus. Numerous cell bodies devoid of 


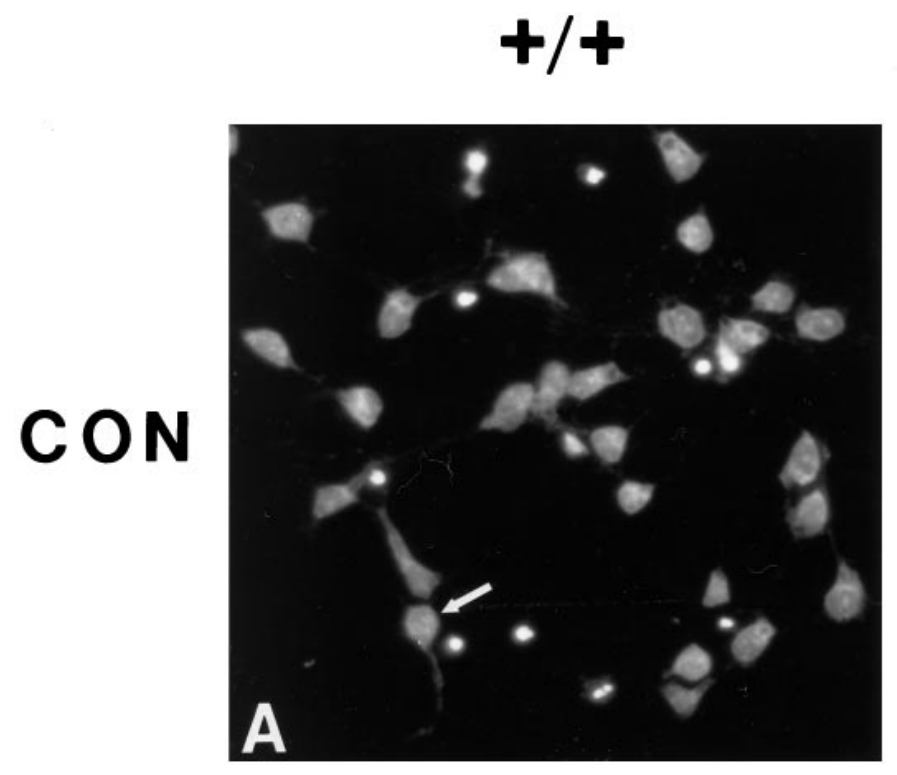

$$
-1-
$$
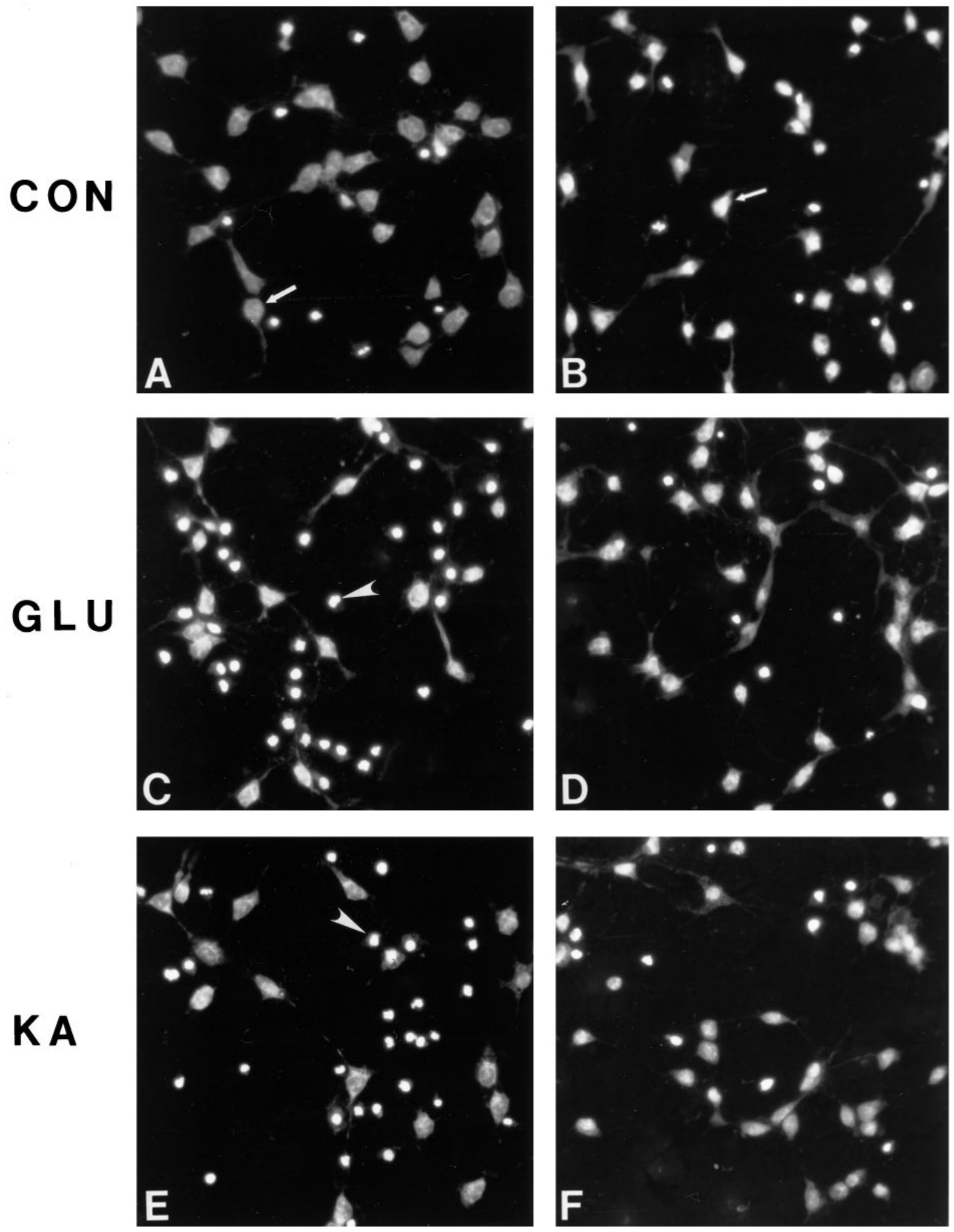

Figure 4. Comparison of nuclear morphology changes induced by glutamate and kainate exposure in p53 $(+/+)(A, C, E)$ and p53 $(-/-)(B, D, F)$ cortical neurons. Neurons were plated and maintained in basal culture conditions for $4 \mathrm{~d}$, as described in Materials and Methods. Neurons were then exposed to glutamate $(50 \mu \mathrm{M})$ or kainate $(40 \mu \mathrm{M})$ for $2 \mathrm{~d}$. The cultures were fixed, permeabilized, and stained with propidium iodide $(5 \mu \mathrm{g} / \mathrm{ml})$. Propidium iodide fluorescence was viewed at its emission maximum of $617 \mathrm{~nm}$. Nontreated cultures are shown in $A$ and $B$, glutamate-treated cultures in $C$ and $D$, and kainate-treated cultures in $E$ and $F$. Examples of large nuclei associated with viable neurons are illustrated by arrows. Examples of apoptotic nuclei exhibiting extreme chromatin condensation are illustrated by arrowheads. Magnification, $840 \times$. 


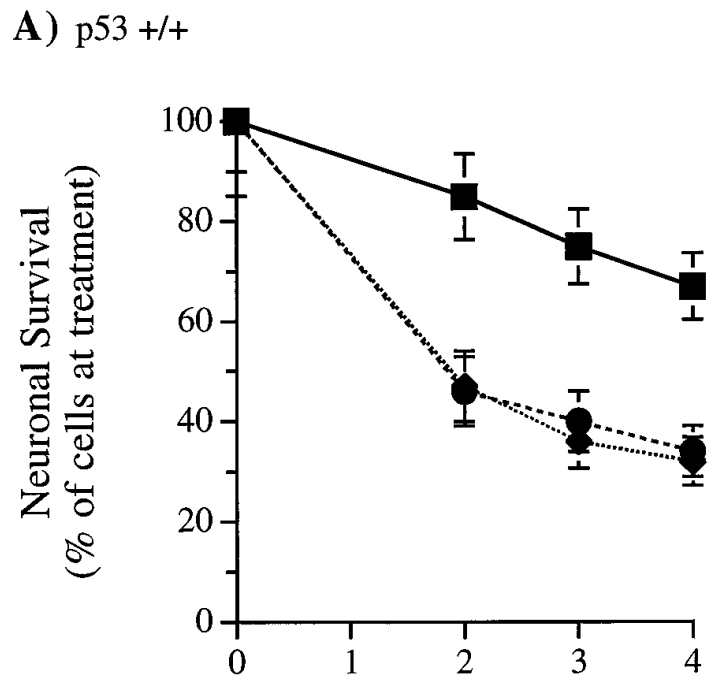

Time (days)

B ) $\mathrm{p} 53-\%$

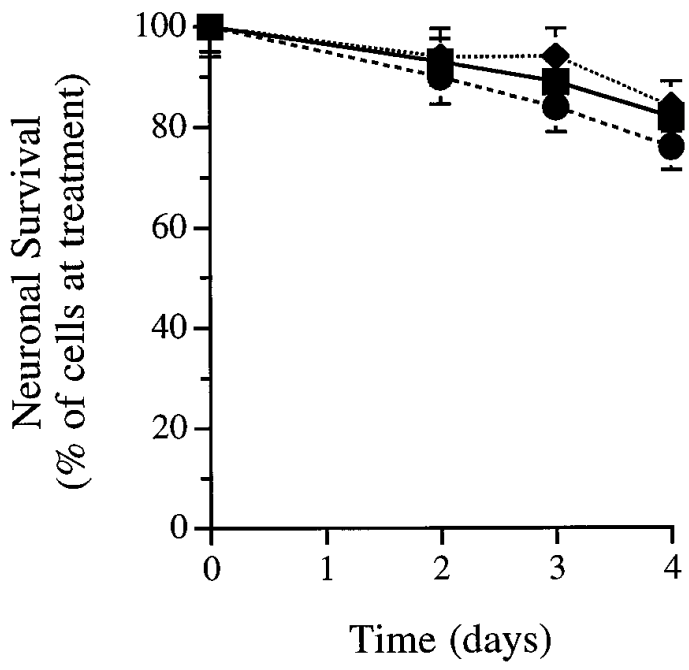

Figure 5. The absence of p53 confers resistance to glutamate- and kainate-mediated cell death in hippocampal neurons. Hippocampal neurons containing p $53(+/+,+/-)$ or deficient in p53 $(-/-)$ were plated, maintained, and treated, as described for cortical neurons in the legend to Figure 3. Neuronal survival was assessed 2, 3, and $4 \mathrm{~d}$ later for control cells (no treatment, solid squares) or cells treated with glutamate $(50 \mu \mathrm{M}$, solid diamonds), or kainate (40 $\mu \mathrm{M}$, solid circles). All data are the mean \pm SEM of six samples. Neurons containing p53 $(+/+)(A)$ showed significant differences between nontreated cells and cells treated with glutamate or kainate $(p<0.0005$, ANOVA). Neuronal survival was not significantly different among nontreated, glutamate-treated, or kainate treated p53deficient neurons $(-/-)(B)(p>0.54)$.

processes remained affixed to the culture substratum, similar to the effects seen in cells undergoing apoptosis, as reported in other studies (Ankarcrona et al., 1995).

The temporal pattern of neuronal cell loss was strongly correlated with the appearance of the p53 protein. Use of the wild-type, human p53 gene simplified detection of the p53 protein, especially

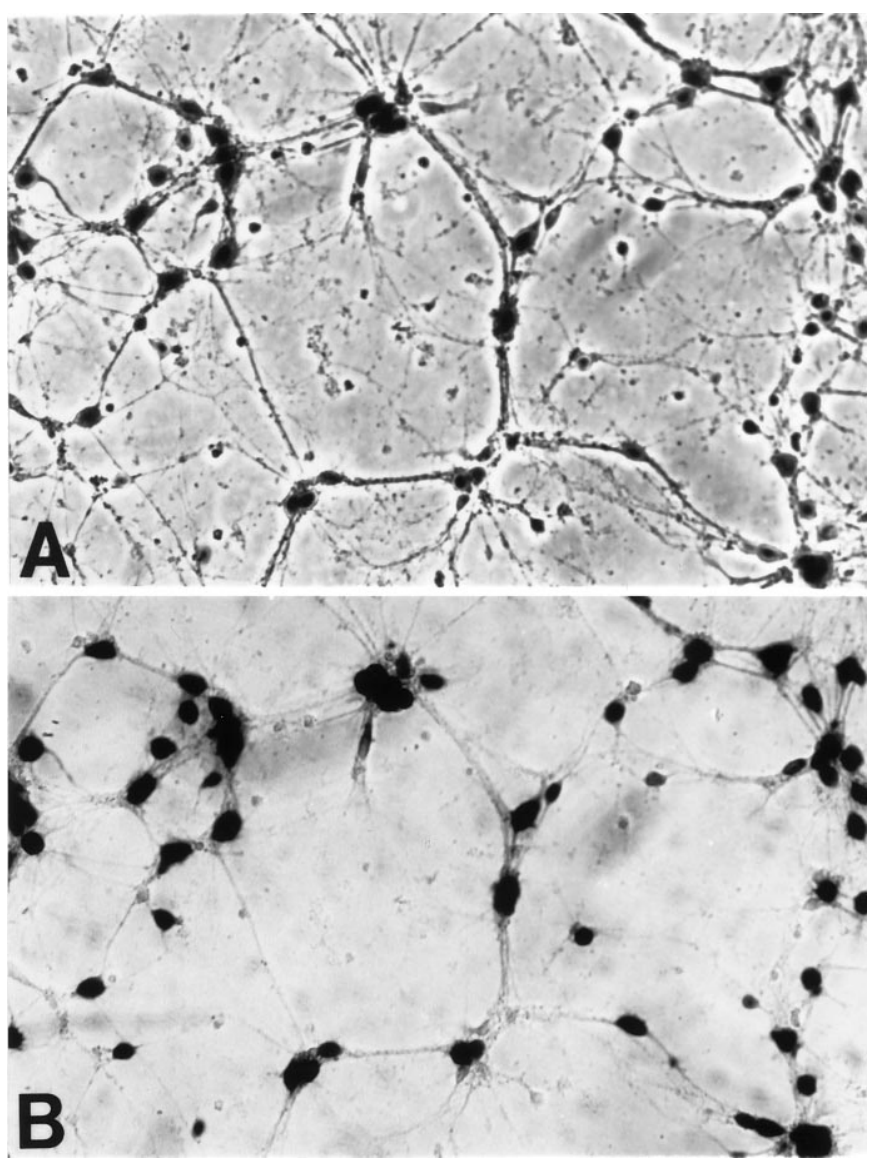

Figure 6. High-level transduction efficiency is associated with adenovirus infection of p53-deficient cortical neurons. Neuronal cultures deficient in p53 (-/-) were plated and maintained in basal culture conditions, as described in Materials and Methods. Three days after plating, cells were infected with adenovirus (MOI, 250) expressing the $\beta$-galactosidase gene. Three days after infection, the cells were fixed and processed for $\beta$-galactosidase activity, as described in Materials and Methods. The cells are viewed under phase-contrast optics $(A)$ and with bright-field conditions $(B)$. The results are representative of three separate experiments. Magnification, $580 \times$.

in wild-type cells, because human-specific antibodies are available that do not cross react with the endogenous mouse protein. p53 immunoreactivity was first detected in the nucleus of neurons $4 \mathrm{hr}$ after infection (Table 2, Fig. 10D). Thereafter, the number of p53 immunoreactive neurons continuously increased over time so that by $3 \mathrm{~d}$ after infection, $\sim 90 \%$ of all p53 $(-/-)$ neurons exhibited intense immunoreactivity for the p53 protein (Fig. $10 H$ ). Identical results were obtained using p53 (-/-) hippocampal neurons. Elevated p53 expression was also associated with increased cell death in p53 wild-type and heterozygous neuronal cultures (data not shown).

\section{DISCUSSION}

Recent reports have shown that kainate administration or adrenalectomy induced p53 expression in neurons exhibiting morphological evidence of damage (Sakhi et al., 1994; Schreiber et al., 1994) and suggested a role for p53 in these cell death processes. To test this hypothesis, we previously used transgenic mice deficient in one or both p53 alleles to examine the effect of p53 loss on neuronal viability after excitotoxic injury (Morrison et al., 1996). The results from that study demonstrated that the absence 


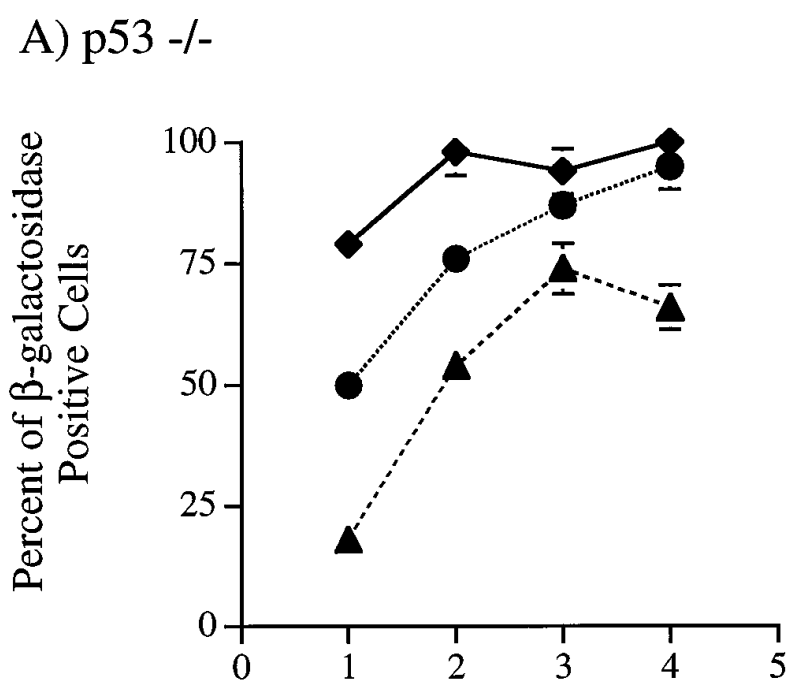

Time (days)
B) $\mathrm{p} 53+/+$

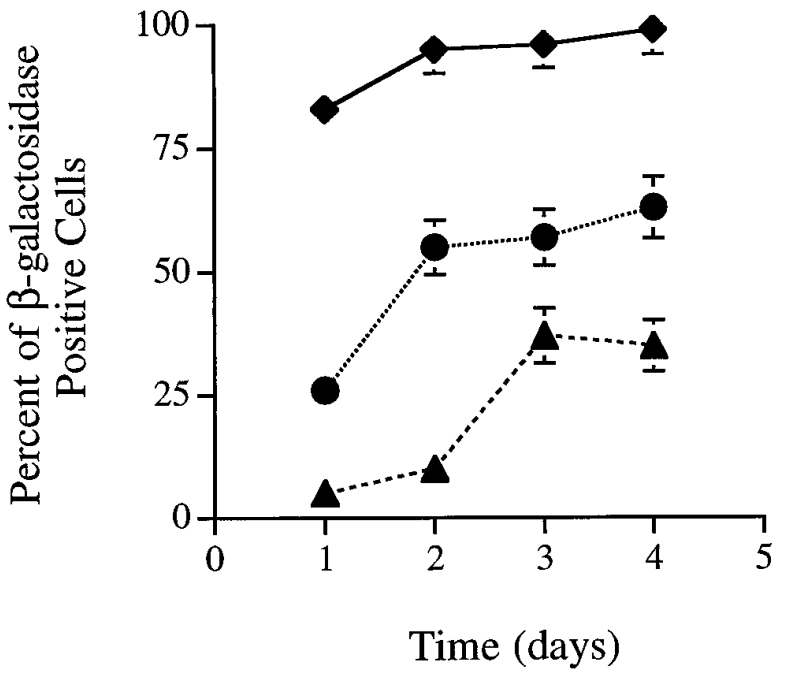

D) $\mathrm{p} 53+/+$

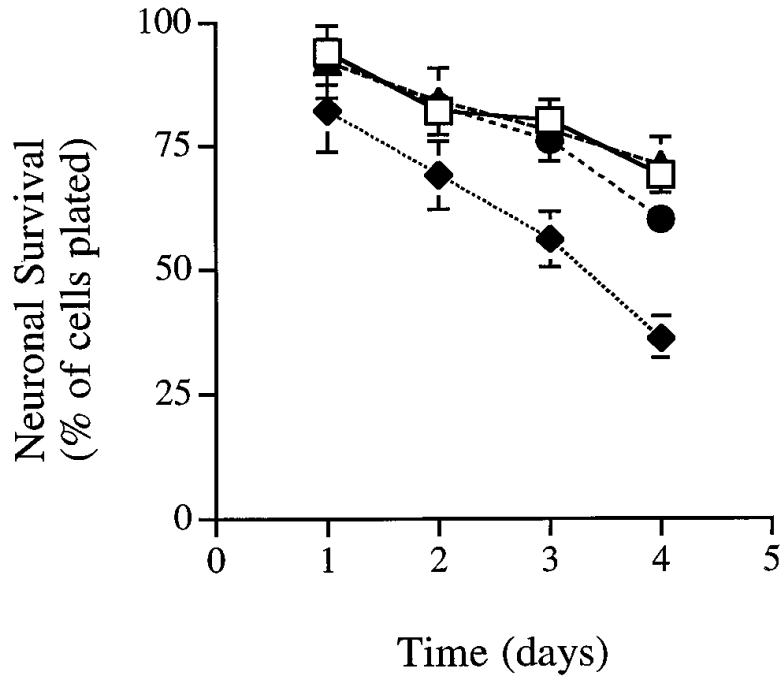

Figure 7. Adenovirus-mediated transduction in cortical neurons. Cortical neurons containing p53 $(+/+)(B, D)$ or those deficient in p53 $(-/-)(A, C)$ were plated and maintained in basal culture conditions, as described in Materials and Methods. Three days after plating, cells were infected with adenovirus expressing the $\beta$-galactosidase gene at different multiplicities of infection (10, solid triangles; 100 , solid circles; 1000, solid diamonds). Cells were infected with virus for $1 \mathrm{hr}$ in Neurobasal medium, washed with HBSS (containing $\mathrm{Ca}^{2+}$ and $\mathrm{Mg}^{2+}$ ), and replenished with a half volume of fresh Neurobasal medium devoid of virus but containing the B27 supplement (Gibco). Cells were examined for $\beta$-galactosidase activity, as described in Materials and Methods. The percentage of $\beta$-galactosidase-positive cells was determined for each MOI $(A, B)$ at $1,2,3$, and $4 \mathrm{~d}$ after infection. Results are expressed as the mean $\pm \mathrm{SD}(n=3$ wells $)$ and are representative of three separate experiments. The influence of viral titer on neuronal viability was also determined $(C, D)$. Neuronal cultures used for determining cell viability were plated in parallel to those used for determining the viral transduction efficiency. The number of neurons per well was determined by direct cell counting for each MOI and for noninfected cultures (open squares). Results represent the mean $\pm \mathrm{SD}(n=3$ wells) and are expressed as the percent of neurons surviving relative to the number of cells at the time of infection. The results are representative of three separate experiments.

of p53 conferred protection on neurons normally damaged by systemic kainate injections and the ensuing seizure activity. However, the p53 knock-out mice used in our study expressed a global p53 deficiency in all cell types, and it was therefore not possible to conclude that protection was conferred by the exclusive absence of p53 in normally affected neurons. In the present study, we determined whether p53 expression in isolated neurons is directly coupled to a loss of viability. Evidence obtained from the present investigation suggests that: (1) in a relatively pure neuronal culture system, p53 directly promotes irreversible neuronal damage after excitotoxic injury; (2) p53 can activate neuronal cell death in the absence of a cytotoxic stimulus; (3) a sustained elevation in 

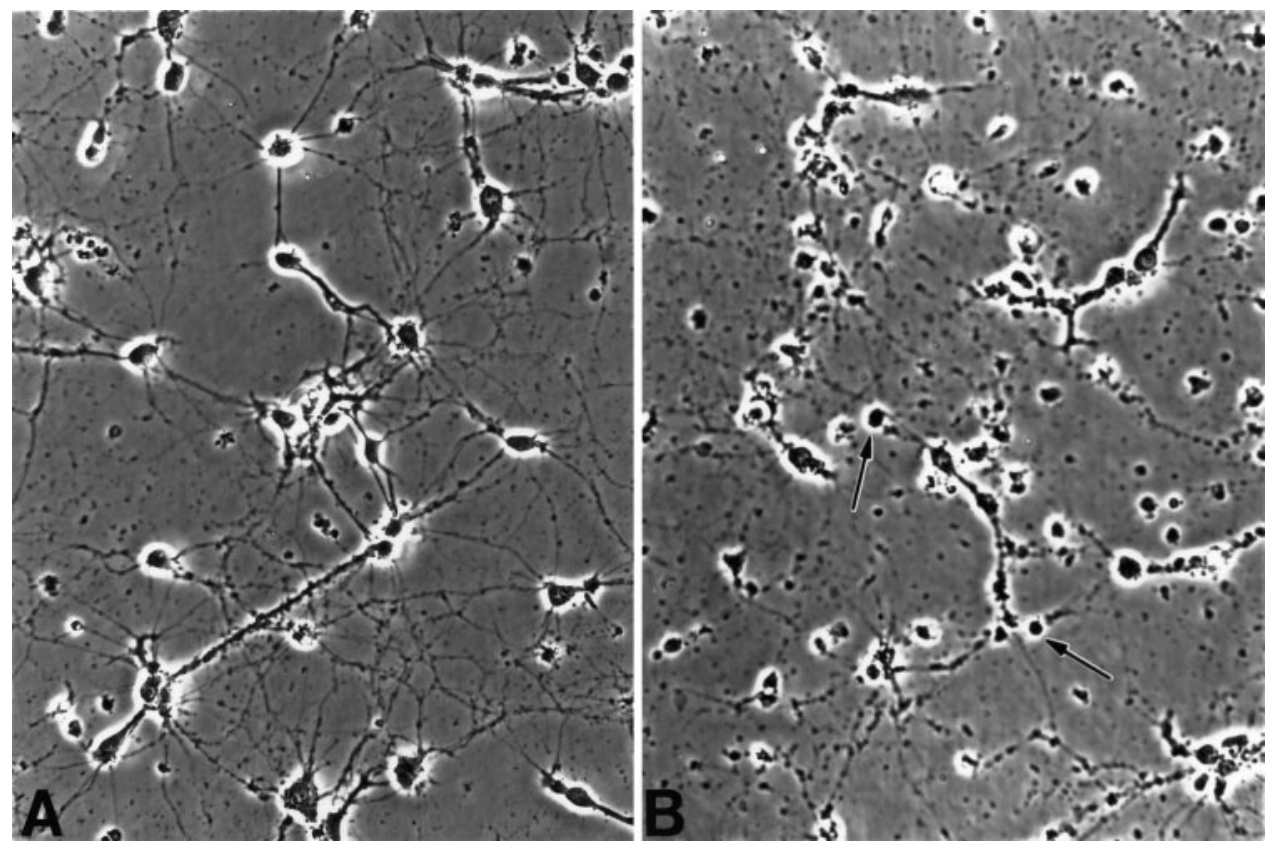

Figure 8. Morphological alterations associated with adenovirus-mediated transduction of the $\beta$-galactosidase or p53 gene into p53-deficient neurons. Cortical neurons (p53 - / - ) were plated and maintained, as described in Materials and Methods. Four days after plating, the cells were infected with adenovirus containing the $\beta$-galactosidase gene $(\mathrm{MOI}=250, A)$ or the human, wild-type p53 gene (MOI = $250, B)$. Cells were photographed $4 \mathrm{~d}$ after infection. Numerous cell bodies in various states of condensation and degeneration are present in p53-infected cultures $(B$, arrows). Magnification, $690 \times$.

intracellular calcium levels, triggered by glutamate exposure, is insufficient to initiate neuronal cell death in the absence of additional signaling molecules, i.e., p53; and (4) the cell culture system using p53 wild-type and p53-deficient neurons mimicked the biological responses observed during the in vivo studies, thus providing a valuable model for elucidating the mechanism of p53mediated cell death. Furthermore, the results obtained with this

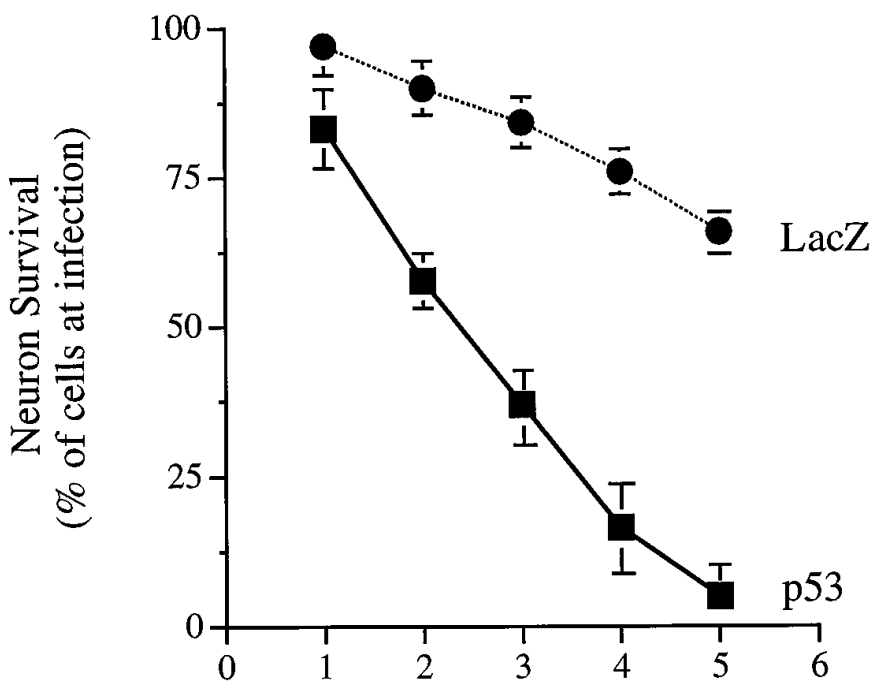

Time (days)

Figure 9. p53 expression promotes cell loss in p53-deficient cortical neuronal cultures. Cortical neurons (p53-/-) were plated and maintained, as described in Materials and Methods. Four days after plating, the cells were infected with adenovirus expressing either the $\beta$-galactosidase gene (solid circles, $\mathrm{MOI}=250, \mathrm{LacZ}$ ) or the human, wild-type p53 gene (solid squares, MOI $=250, \mathrm{p} 53$ ). The number of surviving neurons was determined at $1,2,3,4$, and $5 \mathrm{~d}$ after infection. The data are expressed as the percentage of neurons surviving relative to the number of neurons present at the time of infection (mean $\pm \mathrm{SD}, n=6$ ). The survival of p53-infected neurons was significantly different from neurons infected with the $\beta$-galactosidase gene ( $p<0.0005$, ANOVA). culture model suggest that the influence of p53 in our in vivo studies was related to the direct cellular response after injury, not to an indirect influence or modulation of the toxicity signal. These results strongly support the view that p53 represents an essential element in a pathway that modulates neuronal viability in response to excitotoxic injury.

Our present attempt to define possible differences in the glutamate-initiated input signal between p53 $(+/+)$ and p53 $(-/-)$ neurons centered on alterations in calcium homeostasis. The loss of neuronal viability resulting from excitotoxic injury has been attributed in large part to a sustained elevation in the levels of intracellular free calcium (Choi, 1988, 1992). Increased intracellular calcium is believed to lead to increased cellular swelling and loss of membrane integrity. A number of conflicting studies, however, have demonstrated that there may not be a simple correlation between global measures of intracellular free calcium

Table 2. Temporal course of p53 immunoreactivity after adenovirusmediated transduction of the human wild-type p53 gene into p53 (-/-) cortical neurons

\begin{tabular}{llc}
$\begin{array}{l}\text { Time after } \\
\text { infection }\end{array}$ & Vector & $\begin{array}{l}\text { p53 immunopositive neurons } \\
\text { (\% of cells) }\end{array}$ \\
\hline $2 \mathrm{hr}$ & $\mathrm{p} 53$ & 0 \\
$4 \mathrm{hr}$ & $\mathrm{p} 53$ & $3.6 \pm 0.5$ \\
$8 \mathrm{hr}$ & $\mathrm{p} 53$ & $16.5 \pm 2.6$ \\
$1 \mathrm{~d}$ & $\mathrm{p} 53$ & $39.0 \pm 2.0$ \\
$3 \mathrm{~d}$ & $\mathrm{p} 53$ & $89.0 \pm 9.8$ \\
$5 \mathrm{~d}$ & $\mathrm{p} 53$ & $83.0 \pm 7.7$ \\
$5 \mathrm{~d}$ & LacZ & 0
\end{tabular}

Cortical neurons (p53 -/-) were plated, maintained, and infected with adenovirus expressing the wild-type, human p53 gene, as described in the legend to Figure 9. Cells were fixed and processed for p53 immunocytochemistry at various times after infection ( $2 \mathrm{hr}$ to $5 \mathrm{~d}$ ). The percentage of p53-immunopositive cells was determined using three wells per time point. Each value represents the mean of three wells \pm SD. Staining was not observed with adenovirus expressing the p53 gene at $2 \mathrm{hr}$ after infection or at any time after infection with adenovirus expressing the $\beta$-galactosidase gene. These results are representative of four separate experiments. Because the ratio of plating efficiency to viral titer varied somewhat across experiments, the data from these experiments were not averaged. 

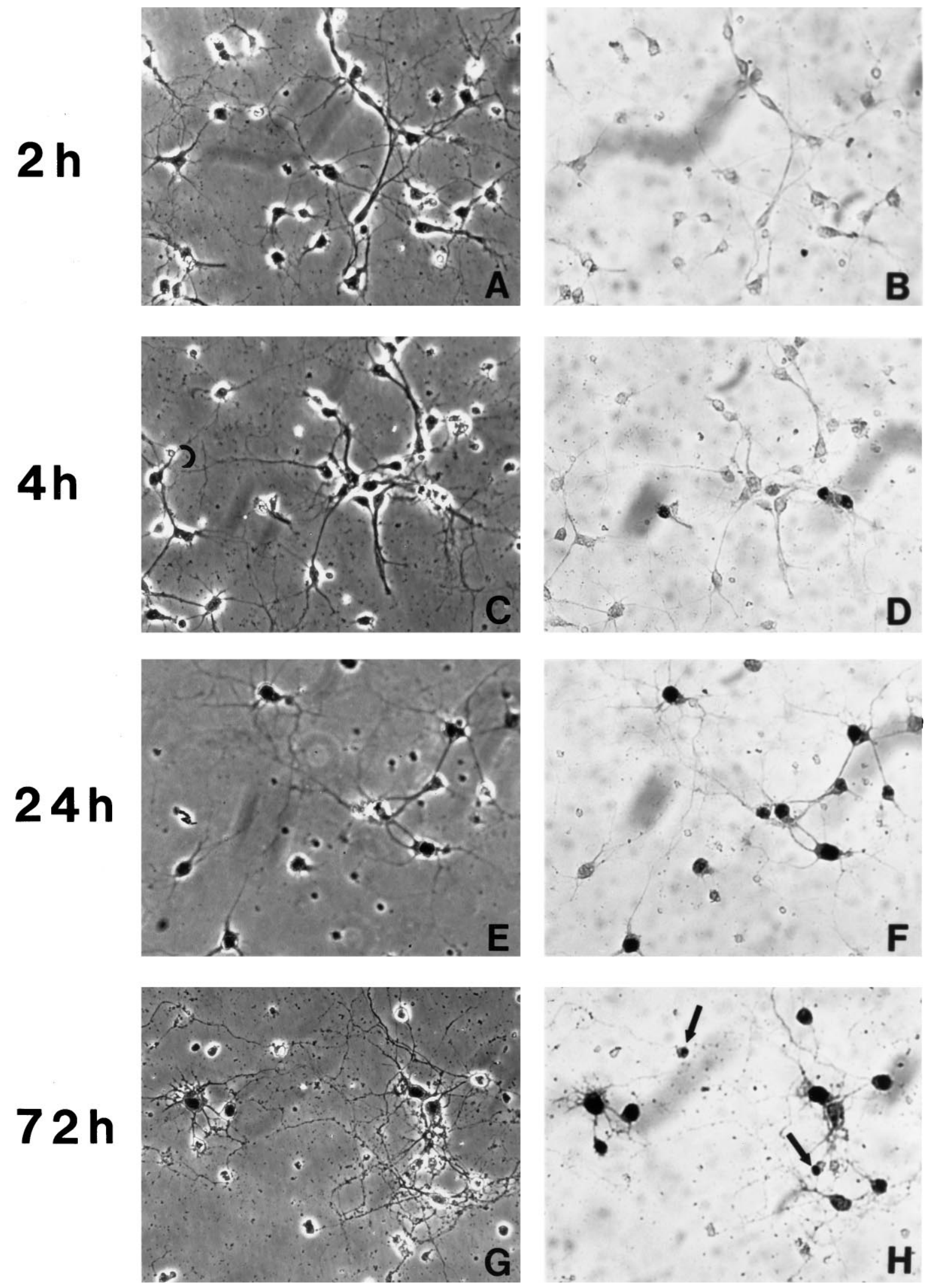

Figure 10. p53 immunoreactivity is present in p53-deficient cortical neurons after infection with adenovirus containing the wild-type, human p53 gene. Cortical neurons (p53 -/-) were plated and maintained, as described in Materials and Methods. Four days after plating, the cells were infected with adenovirus expressing the wild-type, human p53 gene $(\mathrm{MOI}=250)$. Cells were fixed and processed for p53 immunocytochemistry, as described in Materials and Methods, at various times after infection ( $2 \mathrm{hr}$ to $5 \mathrm{~d})$. No staining was observed $2 \mathrm{hr}$ after infection or at any time after infection with the adenovirus expressing the $\beta$-galactosidase gene. Cells are viewed under phase-contrast optics (left column, $A$, $C, E$, $G$ ) and with bright-field conditions to view p53 immunoreactivity (right column, $B, D, F, H$ ). These results are representative of four separate experiments. Magnification, $580 \times$. 
and ensuing cell death (Dubinsky and Rothman, 1991; Tymianski et al., 1993). Rather, excitotoxicity may be characterized by localized disruptions in ionic homeostasis (Bindokas and Miller, 1995). Results from the present study also demonstrate that global, sustained elevations in intracellular free calcium are not sufficient to promote neuronal cell death after glutamate exposure. Wildtype and p53-deficient neurons displayed a similar sustained increase in calcium levels after glutamate exposure, but only the p53 $(+/+)$ cells displayed a marked loss of viability in response to the glutamate challenge. These results suggest that multiple signaling pathways must be activated to carry out an active, gene-directed process of cellular self-destruction. The present studies implicate the p53 gene as an active participant in this process in neurons destined to die in response to excitotoxic injury.

The signal responsible for inducing p53 in injured neurons is not presently known, although DNA damage is the most likely candidate for such a stimulus. Recent evidence suggests that DNA strand breaks, but not other DNA lesions, are capable of inducing p53 accumulation (Jayaraman and Prives, 1995; Lee et al., 1995). Mechanisms for sensing DNA damage and regulating DNA repair in neurons are only beginning to be elucidated (Brooks et al., 1996). The demonstration that neurons containing the p53 gene are sensitive to kainate and glutamate excitotoxicity, whereas p53-deficient neurons are resistant, is consistent with the recent finding that accumulation of single-strand DNA breaks is an early event in cerebellar granule neurons in response to chronic, moderate excitotoxicity (Didier et al., 1996). This association between excitotoxicity and DNA strand breaks provides a potential molecular link between excitotoxic injury and the induction of apoptotic cell death in neurons. Such a link would also be consistent with the proposed role for oxidative damage in the degeneration of neurons during normal aging and in response to disease (Beal, 1995). Glutamate receptor activation and alterations in key detoxifying enzymes (such as superoxide dismutase) have both been linked to the generation of reactive oxygen species including superoxide and nitric oxide (Bondy and Lee, 1993; Lafon-Cazal et al., 1993; Greenlund et al., 1995). These reactive agents, in turn, can produce extensive cellular damage by oxidizing DNA, protein, and lipids (Beckman and Crow, 1993). Investigators have also shown that neurons deficient in nitric oxide synthase (Dawson et al., 1996) or treated with free radical spin traps (Schulz et al., 1995) exhibit attenuated responses to NMDA-mediated excitotoxicity; these findings are consistent with the hypothesis that neuronal injury that produces an excess of free radicals could generate DNA strand breaks (Halliwell and Gutteridge, 1989), which then could provide a signal for activating p53. In our current studies, the survival rate of $\mathrm{p} 53(+/+)$ neurons in basal growth conditions was significantly lower than that of p53 ( $/-)$ neurons; this time-dependent reduction in cell survival observed in wild-type neurons may reflect their response to basal levels of oxidative damage resulting from maintenance in an oxygenated culture environment.

Just as for the activation of the p53 gene, the signaling events associated with p53 expression that produced cell death in neocortical and hippocampal neurons (e.g., in response to adenovirus-mediated transduction of the p53 gene) are not understood. The p53 protein can function as a site-specific transactivator or repressor of transcription (Kern et al., 1991; Seto et al., 1992). Whereas transcriptional activity is likely responsible for p53-mediated growth arrest, the relationship of this activity to induction of apoptosis is controversial (Caelles et al., 1994; Haupt et al., 1995). Nevertheless, p53 could influence viability by mod- ulating transcription of cell death/survival genes. Two genes susceptible to regulation by 553 are Bcl-2 and Bax, which exhibit repression and activation, respectively (Miyashita et al., 1994a,b; Miyashita and Reed, 1995). Bcl-2 blocks cell death after a variety of stimuli (Vaux et al., 1992; Allsopp et al., 1993; Behl et al., 1993; Hockenbery et al., 1993; Kane et al., 1993; Martinou et al., 1994; Strasser et al., 1994), whereas overexpression of Bax accelerates apoptotic cell death (Oltvai et al., 1993).

The application of adenovirus-mediated transduction in conjunction with this culture model should prove helpful in evaluating the mechanism by which p53 promotes neuronal cell death. Transduction efficiencies of $\geq 90 \%$ were routinely obtained without a change in neuronal viability. The present results clearly demonstrated that increasing p53 expression in neurons induced neuronal cell death even in p53 $(-/-)$ cells. It should now be possible to assess which intracellular signaling pathways are activated by p53 in the absence of an injury. For example, it will be of great interest to determine whether increased p53 expression promotes apoptosis in cortical neurons deficient in the Bax gene (Knudson et al., 1995).

Our studies also provide more evidence for the direct role played by $\mathrm{p} 53$ in the cell death processes of neocortical and hippocampal neurons. Large numbers of neurons were efficiently transduced with the $\beta$-galactosidase or $\mathrm{p} 53$ gene using adenovirusmediated gene transfer. Because neuronal viability was not compromised after transduction of the $\beta$-galactosidase gene and the number of neurons expressing the p53 protein corresponded so closely with the loss of viable neurons, we can conclude that neuronal cell death was precipitated by introduction of p53 specifically and not by the infection process itself. Cell death was observable starting at $48 \mathrm{hr}$ after transduction, a time course consistent with the view that expression of the p53 protein is pivotal in this cell death cascade. Transduction of the p53 gene in the absence of a cytotoxic stimulus (i.e., glutamate or kainate) resulted in neuronal cell death, suggesting that the p53 protein initiates an irreversible pathway of self-destruction. This result would be expected if p53 was activated by and acting downstream from some form of cellular insult. Because the levels of p53 expression reached after adenovirus transduction may have exceeded the levels of p53 normally expressed after an injury, additional studies will be required to determine whether induction of physiological levels of p53 are sufficient to initiate cell death processes. It is conceivable that at lower levels of p53 expression, additional pathways must be concomitantly activated to produce neuronal cell death.

Our results indicate that $\mathrm{p} 53$ regulates sensitivity to excitotoxic and oxidative damage in two subpopulations of CNS neurons. It is worth noting, however, that p53 may elicit different biological responses in other subpopulations of neurons. In marked contrast to our results using neocortical and hippocampal neurons, overexpression of the wild-type human p53 gene after microinjection into sympathetic neurons did not promote apoptosis. Indeed, when cell death was induced in post-mitotic sympathetic neurons by removing NGF from their support medium, p53 immunoreactivity actually decreased (Sadoul et al., 1996). Moreover, the absence of p53 does not confer protection on embryonic sensory and sympathetic neurons after the withdrawal of neurotrophins (Davies and Rosenthal, 1994; Sadoul et al., 1996). These results suggest that neurotrophin-deprived peripheral neurons die via a p53independent pathway. Results obtained using other tissues suggest that p53 induction after injury and the coupling be- 
tween p53 induction and apoptosis are highly dependent on the cell type (Midgley et al., 1995). Thus, the regulation of p53 expression and the consequences associated with its activation in the nervous system may vary as a function of the intracellular environment and perhaps the injury stimulus as well. Given these possibilities and the potential role for excitotoxic injury as a stimulus for neuronal cell death in chronic neurodegenerative disorders, stroke, and epilepsy, it will be important to evaluate the relationship between p53 expression and neuronal viability in human neurological disorders (Ikonomidou and Turski, 1995; Portera-Cailliau et al., 1995).

\section{REFERENCES}

Allsopp TE, Wyatt S, Paterson HF, Davies AM (1993) The protooncogene bcl-2 can selectively rescue neurotrophic factor-dependent neurons from apoptosis. Cell 73:295-307.

Ankarcrona M, Dypbukt JM, Bonfoco E, Zhivotovsky B, Orrenius S, Lipton SA, Nicotera P (1995) Glutamate-induced neuronal death: a succession of necrosis or apoptosis depending on mitochondrial function. Neuron 15:961-973.

Barr D, Tubb J, Ferguson D, Scaria A, Lieber A, Wilson C, Perkins J, Kay MA (1995) Strain related variations in adenovirally mediated transgene expression from mouse hepatocytes in vivo: comparisons between immunocompetent and immunodeficient inbred strains. Gene Therapy 2:151-155.

Beal MF (1995) Aging, energy and oxidative stress in neurodegenerative diseases. Ann Neurol 38:357-366.

Beckman JS, Crow JP (1993) Pathological implications of nitric oxide, superoxide and peroxynitrite formation. Biochem Soc Trans 21:330-334.

Behl C, Hovey L, Krajewski S, Schubert D, Reed JC (1993) Bcl-2 prevents killing of neuronal cells by glutamate but not by amyloid beta protein. Biochem Biophys Res Commun 197:949-956.

Bindokas VP, Miller RJ (1995) Excitotoxic degeneration is initiated at non-random sites in cultured rat cerebellar neurons. $J$ Neurosci 15:6999-7011.

Boise LH, González-García M, Postema CE, Ding L, Lindsten T, Turka LA, Mao X, Nuñez G, Thompson CB (1993) Bcl-x, a bcl-2-related gene that functions as a dominant regulator of apoptotic cell death. Cell 74:597-608.

Bondy SC, Lee DK (1993) Oxidative stress induced by glutamate receptor agonists. Brain Res 610:229-233.

Brewer GJ, Torricelli JR, Evege EK, Price PJ (1993) Optimized survival of hippocampal neurons in B27-supplemented neurobasal, a new serum-free medium combination. J Neurosci Res 35:567-576.

Brooks PJ, Marietta C, Goldman D (1996) DNA mismatch repair and DNA methylation in adult brain neurons. J Neurosci 16:939-945.

Caelles C, Helmberg A, Karin M (1994) p53-dependent apoptosis in the absence of transcriptional activation of p53-target genes. Nature 370:220-223.

Choi DW (1988) Glutamate neurotoxicity and diseases of the nervous system. Neuron 1:623-634.

Choi DW (1992) Excitotoxic cell death. J Neurobiol 23:1261-1276.

Chopp M, Li Y, Zhang ZG, Freytag SO (1992) p53 expression in brain after middle cerebral artery occlusion in the rat. Biochem Biophys Res Commun 182:1201-1207.

Davies AM, Rosenthal A (1994) Neurons from mouse embryos with a null mutation in the tumour suppressor gene p53 undergo normal cell death in the absence of neurotrophins. Neurosci Lett 182:112-114.

Dawson VL, Kizushi VM, Huang PL, Snyder SH, Dawson TM (1996) Resistance to neurotoxicity in cortical cultures from neuronal nitric oxide synthase-deficient mice. J Neurosci 16:2479-2487.

Didier M, Bursztajn S, Adamec E, Passani L, Nixon RA, Coyle JT, Wei JY, Berman SA (1996) DNA strand breaks induced by sustained glutamate excitotoxicity in primary neuronal cultures. J Neurosci 16:2238-2250.

Donehower LA, Harvey M, Slagle BL, McArthur MJ, Montgomery CA Jr, Butel JS, Bradley A (1992) Mice deficient for p53 are developmentally normal but susceptible to spontaneous tumours. Nature 356:215-221.

Dubinsky JM, Rothman SM (1991) Intracellular calcium concentrations during "chemical hypoxia" and excitotoxic neuronal injury. J Neurosci 11:2545-2551.
Greenlund LJ, Deckwerth TL, Johnson EM (1995) Superoxide dismutase delays neuronal apoptosis: a role for reactive oxygen species in programmed neuronal death. Neuron 14:303-315.

Halliwell B, Gutteridge JMC (1989) Free radicals in biology and medicine, Ed 2. Oxford: Clarendon.

Haupt Y, Rowan S, Shaulian E, Vousden KH, Oren M (1995) Induction of apoptosis in HeLa cells by trans-activation-deficient p53. Genes Dev 9:2170-2183.

Hockenbery DM, Oltvai ZN, Yin XM, Milliman CL, Korsmeyer SJ (1993) Bcl-2 functions in an antioxidant pathway to prevent apoptosis. Cell 75:241-251.

Ikonomidou C, Turski L (1995) Excitotoxicity and neurodegenerative diseases. Curr Opin Neurol 8:487-497.

Jayaraman JL, Prives C (1995) Activation of p53 sequence-specific DNA binding by short single strands of DNA requires the p53 C-terminus. Cell 81:1021-1029.

Kane DJ, Sarafian TA, Anton R, Hahn H, Gralla EB, Valentine JS, Örd T, Bredesen DE (1993) Bcl-2 inhibition of neural death: decreased generation of reactive oxygen species. Science 262:1274-1277.

Kanegae Y, Lee G, Sato Y, Tanaka M, Nakai M, Sakaki T, Sugano S, Saito I (1995) Efficient gene activation in mammalian cells by using recombinant adenovirus expressing site-specific Cre recombinase. Nucleic Acids Res 23:3816-3821.

Kern SE, Kinzler KW, Bruskin A, Jarosz D, Friedman P, Prives C, Vogelstein B (1991) Identification of p53 as a sequence-specific DNAbinding protein. Science 252:1708-1711.

Knudson CM, Tung KS, Tourtellotte WG, Brown GA, Korsmeyer SJ (1995) Bax-deficient mice with lymphoid hyperplasia and male germ cell death. Science 270:96-99.

Lafon-Cazal M, Pietri S, Culcasi M, Bockaert J (1993) NMDA-dependent superoxide production and neurotoxicity. Nature 364:535-537.

Lee S, Elenbaas B, Levine A, Griffith J (1995) p53 and its $14 \mathrm{kDa}$ C-terminal domain recognize primary DNA damage in the form of insertion/deletion mismatches. Cell 81:1013-1020.

Li Y, Chopp M, Zhang ZG, Zaloga C, Niewenhuis L, Gautam S (1994) p53-immunoreactive protein and p53 mRNA expression after transient middle cerebral artery occlusion in rats. Stroke 25:849-855.

Martinou JC, Dubois-Dauphin M, Staple JK, Rodriguez I, Frankowski H, Missotten M, Albertini P, Talabot D, Catsicas S, Pietra C, Huarte J (1994) Overexpression of bcl-2 in transgenic mice protects neurons from naturally occurring cell death and experimental ischemia. Neuron 13:1017-1030.

Midgley CA, Owens B, Briscoe CV, Thomas DB, Lane DP, Hall PA (1995) Coupling between gamma irradiation, p53 induction and the apoptotic response depends upon cell type in vivo. J Cell Sci 108:1843-1848.

Miyashita T, Reed JC (1995) Tumor suppressor p53 is a direct transcriptional activator of the human bax gene. Cell 80:293-299.

Miyashita T, Harigai M, Hanada M, Reed JC (1994a) Identification of a p53-dependent negative response element in the bcl-2 gene. Cancer Res 54:3131-3135.

Miyashita T, Krajewski S, Krajewska M, Wang HG, Lin HK, Liebermann DA, Hoffman B, Reed JC (1994b) Tumor suppressor p53 is a regulator of bcl-2 and bax gene expression in vitro and in vivo. Oncogene 9:1799-1805.

Morrison RS,Wenzel HJ, Kinoshita Y, Robbins CA,Donehower LA, Schwartzkroin PA (1996) Loss of the p53 tumor suppressor gene protects neurons from kainate-induced cell death. J Neurosci 16:1337-1345.

Motoyama N, Wang F, Roth KA, Sawa H, Nakayama K, Nakayama K, Negishi I, Senju S, Zhang Q, Fujii S, Loh DY (1995) Massive cell death of immature hematopoietic cells and neurons in Bcl-x-deficient mice. Science 267:1506-1510.

Oltvai ZN, Milliman CL, Korsmeyer SJ (1993) Bcl-2 heterodimerizes in vivo with a conserved homolog, bax, that accelerates programmed cell death. Cell 74:609-619.

Portera-Cailliau C, Hedreen JC, Price DL, Koliatsos VE (1995) Evidence for apoptotic cell death in huntington disease and excitotoxic animal models. J Neurosci 15:3775-3787.

Sadoul R, Quiquerez AL, Martinou I, Fernandez PA, Martinou JC (1996) p53 protein in sympathetic neurons: cytoplasmic localization and no apparent function in apoptosis. J Neurosci Res 43:594-601.

Sakhi S, Bruce A, Sun N, Tocco G, Baudry M, Schreiber SS (1994) p53 induction is associated with neuronal damage in the central nervous system. Proc Natl Acad Sci USA 91:7525-7529. 
Schreiber SS, Sakhi S, Dugich-Djordjevic MM, Nichols NR (1994) Tumor suppressor p53 induction and DNA damage in hippocampal granule cells after adrenalectomy. Exp Neurol 130:368-376.

Schulz JB, Henshaw DR, Siwek D, Jenkins BG, Ferrante RJ, Cipolloni PB, Kowall NW, Rosen BR, Beal MF (1995) Involvement of free radicals in excitotoxicity in vivo. J Neurochem 64:2239-2247.

Seto E, Usheva A, Zambetti GP, Momand J, Horikoshi N, Weinmann R, Levine AJ, Shenk T (1992) Wild-type p53 binds to the TATA-binding protein and represses transcription. Proc Natl Acad Sci USA 89:12028-12032.

Strasser A, Harris AW, Jacks T, Cory S (1994) DNA damage can induce apoptosis in proliferating lymphoid cells via p53-independent mechanisms inhibitable by bcl-2. Cell 79:329-339.

Timme TL, Thompson TC (1994) Rapid allelotype analysis of p53 knockout mice. Biotechniques 17:460-463.

Tymianski M, Charlton MP, Carlen PL, Tator CH (1993) Source speci- ficity of early calcium neurotoxicity in cultured embryonic spinal neurons. J Neurosci 13:2085-2104.

Vaux DL, Weissman IL, Kim SK (1992) Prevention of programmed cell death in Caenorhabditis elegans by human bcl-2. Science 258:1955-1957.

White E (1996) Life, death, and the pursuit of apoptosis. Genes Dev 10:1-15.

Williams GT, Smith CA (1993) Molecular regulation of apoptosis: genetic controls on cell death. Cell 74:777-779.

Zhang WW, Fang X, Branch CD, Mazur W, French BA, Roth JA (1993) Generation and identification of recombinant adenovirus by liposome-mediated transfection and PCR analysis. Biotechniques $15: 868-872$

Zhong LT, Sarafian T, Kane DJ, Charles AC, Mah SP, Edwards RH, Bredesen DE (1993) Bcl-2 inhibits death of central neural cells induced by multiple agents. Proc Natl Acad Sci USA 90:4533-4537. 